Reviu Akuntansi dan Bisnis Indonesia, Vol. 4 No. 1, Hlm: 1-16, Juli 2020

Website: http://journal.umy.ac.id/index.php/rab

\title{
Pengaruh Penerapan Sistem Akuntansi Keuangan Pemerintah Daerah dan Sistem Pengendalian Internal Terhadap Kualitas Laporan Keuangan Pemerintah Daerah Dengan Kompetensi Sumber Daya Manusia Sebagai Variabel Moderasi (Studi Empiris Pada Satuan Kerja Perangkat Daerah Kabupaten Klaten)
}

\author{
Kartika Dwi Indrayani ${ }^{1 *}$ \& Harjanti Widiastuti ${ }^{1}$ \\ 'Program Studi Akuntansi Univeritas Muhammadiyah Yogyakarta.
}

I N F O A R T I K E L

\section{Kata Kunci:}

Regional Financial

Accounting System,

Internal Control System,

Human Resource

Competency, Quality of

Financial Report

Jenis Artikel:

Penelitian Empiris

Korespondensi:

Kartikaindrayani06@gmail.com
A B S T R A K

Latar Belakang:

Pemerintah dituntut untuk melakukan pertanggungjawaban dan transparansi penggunaan anggaran pemerintah daerah. Pemerintah daerah sebagai salah satu organisasi sektor publik, seharusnya menyajikan laporan keuangan yang transparan dan akuntabel. Peneliti menduga sumber daya manusia dapat memoderasi sistem pengendalian internal dan sistem akuntansi keuangan daerah terhadap kualitas laporan keuangan.

Tujuan:

Penelitian ini bertujuan untuk mengetahui pengaruh Sistem Akuntansi Keuangan Daerah dan Sistem Pengendalian Internal terhadap Kualitas Laporan Keuangan Pemerintah Daerah dengan Kompetensi Sumber Daya Manusia sebagai variabel Moderasi.

Metode Penelitian:

Penelitian ini menggunakan teknik purposive sampling, sampel dari penelitian ini diperoleh dari pegawai SKPD Kabupaten Klaten berjumlah 88. Metode analisis penelitian ini menggunakan Moderated Regression Analysis (MRA) dengan menggunakan alat analisis yaitu SPSS 15.

Hasil Penelitian:

Hasil penelitian menunjukkan bahwa variabel Sistem Akuntansi Keuangan Daerah tidak mempengaruhi Kualitas Laporan Keuangan Pemerintah Daerah, Sistem Pengendalian Internal berpengaruh positif terhadap Kualitas Laporan Keuangan Pemerintah Daerah, Kompetensi Sumber Daya Manusia berpengaruh positif dalam memoderasi Sistem Akuntansi Keuangan Daerah dan Sistem Pengendalian Intern atas Kualitas Laporan Keuangan Pemerintah Daerah.

Keterbatasan Penelitian:

Penelitian ini terbatas untuk perangkat desa kabupaten Klaten, maka masih perlu dilakukan penelitian lebih lanjut untuk mengetahui penerapan sistem informasi akuntansi tingkat pemerintah daerah.

Keaslian/Novetly Penelitian:

Penelitian ini menguji peran kompetensi SDM sebagai pemoderasi dalam meningkatkan kualitas laporan keuangans, khususnya bidang sistem informasi akuntansi pada pemerintah daerah. 


\section{PENDAHULUAN}

Berkembangnya Akuntansi Sektor Publik di Indonesia maka hal yang paling utama dilakukan oleh pemerintahan, yaitu mewujudkan pertanggungjawaban terhadap masyarakat (Soimah, 2004). Pemerintah dituntut untuk melakukan pertanggungjawaban dan transparansi penggunaan anggaran pemerintah daerah. Pemerintah daerah sebagai salah satu organisasi sektor publik, seharusnya menyajikan laporan keuangan yang transparan dan akuntabel.

Setelah ditetapkannya Undang-Undang No 22 dan No 25 Tahun 1999 dapat ditarik kesimpulan bahwa Indonesia telah melaksanakan otonomi daerah, yaitu sejak tahun 2000. Daerah otonom sendiri meliputi provinsi, kabupaten maupun kota dimana pemerintahannya adalah pemerintahan provinsi, pemerintahan kabupaten, dan pemerintahan kota. Pemerintahan tersebut tidak terlepas dari adanya aspek keuangan yang mana dikelola oleh pemerintah daerah. Laporan keuangan yang disajikan secara transparan merupakan bentuk dari pertangggungjawaban pemerintah (Andini \& Yusrawati 2015).

Dalam meningkatkan kualitas pemerintah daerah, tuntutan masyarakat bisa dijadikan sebagai acuan agar bisa menjadi pemerintah yang lebih baik (good governance) sehingga pemerintah daerah dalam menyusun laporan keuangan harus transparan dan dapat dipertanggungjawabkan. Pihak yang memakai laporan keuangan tersebut tentunya mengakses laporan keuangan yang telah disediakan pemerintah daerah maka dari itu informasi yang ada di dalamnya harus benar-benar bermanfaat untuk para penggunanya (Putra, 2018).

Laporan keuangan yang disusun pemerintah daerah saat ini sudah terbilang cukup berkualitas dan bisa dikatakan baik. Hal ini bisa dilihat dari opini audit yang diberikan BPK pada pemerintah daerah, tak sedikit pemerintah daerah yang mendapatkan opini Wajar Tanpa Pengecualian (WTP) secara berturut-turut artinya, pemerintah daerah sudah menyusun laporan keuangan sesuai dengan standar pelaporan keuangan. Perolehan predikat WTP tidaklah bisa menjadi tujuan akhir pada penyusunan laporan keuangan. Dengan perolehan predikat tersebut, pemerintah harusnya melakukan evaluasi kembali terhadap hal-hal apa saja yang bisa dimaksimalkan terutama dalam hal efisiensi anggaran.

Menurut data yang ditunjukkan pada Annual Report BPK perwakilan Jawa Tengah tahun 2015-2017 masih terdapat beberapa pemerintah daerah yang memperoleh opini BPK Wajar Dengan Pengecualian (WDP). Data perolehan opini audit BPK untuk Pemerintah Daerah di Jawa Tengah dapat dilihat pada tabel dibawah ini:

Tabel 1

Opini Audit BPK Perwakilan Jawa Tengah 2015-2017

\begin{tabular}{clccc}
\hline \multirow{2}{*}{ No } & \multicolumn{1}{c}{ Opini BPK } & 2015 & 2016 & 2017 \\
\hline 1 & Wajar Tanpa Pengecualian (WTP) & 21 & 31 & 32 \\
2 & Wajar Tanpa Pengecualian Dengan & - & - & - \\
3 & Paragraf Penjelas (WTP-DPP) & 15 & 5 & 4 \\
4 & Wajar Dengan Pengecualian (WDP) & - & - & - \\
\hline
\end{tabular}

Sumber : Annual Report BPK perwakilan Jawa Tengah tahun 2015-2017

Dalam opini audit pada masing-masing pemerintah daerah yang ada di provinsi Jawa Tengah dapat dilihat bahwa Opini BPK Wajar Tanpa Pengecualian (WTP) yang diberikan semakin tahun semakin meningkat. Walaupun secara keseluruhan telah mengalami peningkatan, tetapi pada tahun 2017 masih ada pemerintah daerah yang mendapatkan opini Wajar Dengan Pengecualian (WDP), salah satunya adalah Kabupaten Klaten yang masih memperoleh opini audit Wajar Dengan Pengecualian (WDP), artinya belum semua laporan keuangan pemerintah daerah diakui WTP oleh BPK atau belum sepenuhnya berkualitas. Terbukti dengan laporan keuangan pemerintah 
daerah masih ada yang belum sesuai dengan standar-standar yang seharusnya ditetapkan pada laporan keuangan pemerintah daerah.

Pemeriksaan audit BPK tidak hanya terbatas pada pemeriksaan laporan keuangan saja tetapi juga dinilai kesesuaiannya pada Sistem Pengendalian Intern (SPI) yang diterapkan pada masingmasing pemerintah daerah. Fakta di lapangan menyebutkan bahwa sistem pengendalian intern menjadi prioritas utama bagi pelaksanaan audit yang dilakukan oleh BPK maupun lembagalembaga lainnya (Agustiawan dan Rasmini, 2016). Sistem pengendalian intern berisi seluruh proses, sistem, dan tahapan-tahapan yang harus dilakukan dalam penyusunan laporan keuangan pemerintah.

Dalam menyusun laporan keuangan pemerintah, sistem pengendalian intern memiliki peran didalamnya dimana sistem pengendalian intern ini sebagai pengendali dan pengawas penyusunan laporan keuangan agar dapat dilaporkan dan disusun dengan benar, tepat waktu, tepat sasaran, dan sesuai dengan standar agar memperoleh opini audit yang baik, dengan demikian bahwa sistem pengendalian internal diduga berpengaruh terhadap kualitas laporan keuangan. Hal ini sejalan dengan beberapa hasil penelitian yang telah dilakukan oleh Kiranayanti dan Erawati (2016) serta Munasyir (2015) namun terdapat penelitian yang dilakukan oleh Budiawan dan Purnomo (2014) dan Desipradani dan Nuraini (2018) menemukan hubungan negatif antara sistem pengendalian intern terhadap kualitas laporan keuangan

Selain Sistem Pengendalian Intern (SPI), Sistem Akuntansi Keuangan Daerah (SAKD) juga berperan penting dalam penyusunan laporan keuangan. Dalam hal ini, penggunaan Sistem Akuntansi Keuangan Daerah (SAKD) yang meliputi proses pencatatan, penggolongan, penafsiran, serta pelaporan keuangan dalam rangka pertanggungjawaban pelaksanaan APBD baik menggunakan sistem atau dilakukan secara manual (Permendagri No 59 Tahun 2007) yang diharapkan dapat mewujudkan tercapainya transparansi dan akuntabilitas.

Jika Sistem Akuntansi Keuangan Daerah diterapkan dengan baik, maka Kualitas Laporan Keuangan Pemerintah Daerah semakin baik. Karena pada dasarnya sistem akuntansi merupakan suatu kesatuan yang apabila tidak diterapkan akan sulit memenuhi karakteristik kualitatif Laporan Keuangan Pemerintah Daerah yang sesuai dengan Standar Akuntansi Pemerintah (SAP). Hal ini sejalan dengan hasil penelitian yang telah dilakukan pada penelitian Mahaputra dan Putra (2014) serta Andini dan Yusrawati (2015) namun terdapat penelitian yang dilakukan oleh Kartopawiro dan Susanto (2018) yang menyatakan sistem akuntansi keuangan pemerintah daerah tidak berpengaruh terhadap kualitas laporan keuangan pemerintah daerah.

Menurut Indriasari (2008), kompetensi adalah karakteristik yang dimiliki individu berkaitan dengan keterampilan, pengetahuan, dan kemampuan dalam melaksanakan tugas yang diberikan kepada individu tersebut. Untuk menciptakan laporan keuangan yang berkualitas perlu ditingkatkannya SDM yang faham akan akuntansi pemerintah dan operasional tentang pemerintahan. Menurut Andini dan Yusrawati (2015), kurangnya pegawai yang berlatar pendidikan akuntansi menjadikan pemahaman aparatur Satuan Kerja Pemerintah Daerah (SKPD) kurang dalam mengelola keuangan daerah dengan baik dan benar.

Kompetensi sumber daya manusia dapat memengaruhi terhadap baik buruknya kualitas laporan keuangan yang dihasilkan, sumber daya yang dimaksudkan adalah yang mampu menyusun laporan keuangan berdasarkan standar dan yang memahami jalannya akuntansi pemerintahan, baik dalam hal keuangan daerah maupun operasional pemerintahan. Kurangnya kompetensi sumber daya manusia yang memahami standar penyusunan laporan keuangan pemerintah menjadikan laporan keuangan tersebut belum dapat dikatakan berkualitas. Beberapa riset yang dilakukan oleh Agustiawan dan Rasmini (2016) serta Andini dan Yusrawati (2015) menemukan bahwa terdapat hubungan positif antara sumber daya manusia terhadap kualitas laporan keuangan pemerintah daerah namun terdapat penelitian yang dilakukan oleh Firdaus dkk (2015) yang menyatakan hubungan negatif antara sumber daya manusia terhadap kualitas laporan keuangan pemerintah daerah.

Peneliti menduga sumber daya manusia dapat memoderasi sistem pengendalian internal dan sistem akuntansi keuangan daerah terhadap kualitas laporan keuangan. Alasan dugaan karena apabila sumberdaya manusia memiliki kompetensi yang baik maka dalam memahami dan 
menerapkan suatu sistem akuntansi keuangan daerah dan sistem pengendalian intern juga baik yang tentunya hal ini dapat meningkatkan kualitas laporan keuangan. Sumber daya manusia tidak hanya dilihat dari kompetensi yang dimiliki namun juga dapat dinilai dari tingkat tanggung jawab yang dimiliki oleh sumber daya tersebut.

Dari latar belakang yang dipaparkan di atas, peneliti tertarik untuk meneliti "Penerapan Sistem Akuntansi Keuangan Pemerintah Daerah Dan Sistem Pengendalian Internal Terhadap Kualitas Laporan Keuangan Pemerintah Daerah Dengan Kompetensi Sumber Daya Manusia Sebagai Variabel Moderasi (Studi Empiris pada Satuan Kerja Perangkat Daerah Kabupaten Klaten)”. Penelitian ini merupakan penelitian replikasi dari (Karsana \& Suaryana, 2017). Hal yang membedakan penelitian ini dengan penelitian sebelumnya adalah mengganti variabel Standar Akuntansi Pemerintah dengan variabel Sistem Akuntansi Keuangan Daerah dan dalam penelitian ini menggunakan Kompetensi Sumber Daya Manusia sebagai variabel pemoderasi.

Penelitian ini diharapkan mampu memberi sumbangsih secara teoritis, yaitu mampu menjadi tambahan refrensi bagi riset terkait dengan topik dan dapat membantu untuk mengkonfirmasi teori stewardship, teori agency, dan teori kompetensi spencer dalam penelitian selanjutnya. Secara praktis, penelitian ini diharapkan dapat dijadikan pertimbangan oleh pemerintah daerah dalam pengambilan kebijakan dalam mengembangkan pemanfaatan sistem pengendalian internal, sistem akuntansi keuangan pemerintah daerah, dan kompetensi sumber daya manusia dalam rangka meningkatkan kualitas laporan keuangan.

\section{TINJAUAN LITERATUR DAN PERUMUSAN HIPOTESIS}

\section{Stewardship Theory}

Teori stewardship ini sejalan antara hubungan pemerintah dengan masyarakat, dimana pemerintah sebagai steward yang mengelola sumber daya dan masyarakat sebagai pemilik, pemerintah sebagai steward memiliki tugas melayani publik dan juga mensejahterakan masyarakat. Implikasi teori stewardship terhadap penelitian ini yaitu dapat menjelaskan eksistensi pemerintah daerah sebagai suatu lembaga yang dapat dipercaya, dapat menampung aspirasi masyarakat, dapat memberikan pelayanan yang baik bagi publik, serta mampu membuat pertanggungjawaban keuangan yang diamanahkan kepadanya, sehingga tujuan ekonomi terpenuhi serta kesejahteraan masyarakat dapat tercapai secara maksimal.

\section{Agency Theory}

Keterkaitan adanya teori agensi dalam penelitian ini dapat dilihat dalam pelaporan keuangan, dimana pemerintah bertindak sebagai pihak yang diberi amanah (agen) maka berkewajiban untuk mengungkapkan segala informasi yang dibutuhkan oleh para pihak yang memiliki kepentingan sebagai pengguna informasi yang dimana bertindak sebagai principal untuk menilai akuntabilitas dan memutuskan kebijakan sosial, politik, maupun ekonomi baik yang terlibat secara langsung maupun tidak langsung melalui wakil-wakilnya. Hubungan antara pemerintah dan pemilik kepentingan sebagai pengguna informasi laporan keuangan dapat dikaitkan adanya hubungan keagenan.

\section{Teori Kompetensi Spancer}

Kompetensi adalah karakteristik dasar seseorang yang berkaitan dengan efektivitas kinerja dan dapat digunakan untuk menilai kinerja seseorang. Kompetensi juga dapat digunakan untuk mengukur kinerja seseorang dengan kriteria tertentu. Ada lima karakteristik kompetensi yang disebutkan oleh Spencer dan Spencer (1993), yaitu motivates (suatu hak yang membuat seseorang secara konsisten melakukan tindakan tertentu), traits (sifat seseorang dalam merespon situasi 
tertentu), self concept (sikap seseorang), knowledge (pengetahuan dibidang tertentu), dan skills (kemampuan yang dimiliki pada bidang tertentu).

\section{Sistem Akuntansi Keuangan Pemerintah Daerah}

Sistem akuntansi keuangan daerah dalam hal pelaporan keuangan memilki fungsi sebagai pertanggungjawaban, manajerial, hingga pengawasan. Hal tersebut berkaitan dengan kualitas dari laporan keuangan, apabila laporan keuangan dipertanggungjawabkan dengan baik yang artinya memberikan informasi keuangan yang lengkap, cermat, sesuai dengan pedoman, hingga dalam bentuk dan waktu yang tepat, maka kualitas dari laporan keuangan akan memperoleh karakteristik yang telah ditetapkan, karena pada dasarnya sistem akuntansi merupakan suatu kesatuan yang apabila tidak diterapkan maka akan sulit memperoleh laporan keuangan yang berkualitas.

\section{$H_{i}$ : Penerapan SAKD berpengaruh positif terhadap kualitas laporan keuangan pemerintah daerah}

\section{Sistem Pengendalian Internal}

Menurut Rai (2008), Sistem pengendalian intern merupakan suatu kebijakan dan prosedur yang dirancang dalam rangka untuk memberikan keyakinan bagi manajemen bahwa suatu organisasi tersebut mencapai tujuan dan sasarannya. Sistem pengendalian internal dalam suatu organisasi menjadi hal yang utama dan sangat dibutuhkan karena suatu kegiatan operasional memerlukan suatu kebijakan khusus yang mampu membatasi dan mengkoordinasi dalam setiap kegiatan yang dilaksanakan. Suatu organisasi termasuk pemerintah berkewajiban melakukan pengendalian terhadap kegiatan pemerintah dalam menyusun laporan keuangan, adanya sistem pengendalian intern yang baik, maka segala kegiatan terutama di bidang keuangan akan berjalan sesuai dengan prosedur, sehingga mampu menghasilkan laporan keuangan yang berkualitas.

\section{$\boldsymbol{H}_{2}$ : Sistem pengendalian internal berpengaruh positif terhadap kualitas laporan keuangan pemerintah daerah}

\section{Kompetensi Sumber Daya Manusia}

Sumber daya manusia merupakan salah satu sumber daya yang terdapat dalam organisasi, meliputi semua orang yang melakukan kegiatan (Gomes, 2003). Manusia adalah salah satu faktor sumber daya yang sangat penting dalam upaya tercapainya tujuan dalam organisasi, sehingga perlu dikelola dengan sebaik mungkin agar dapat memberikan kontribusi yang maksimal. Kompetensi sumber daya manusia mencakup kapasitasnya, yaitu kemampuan seseorang atau individu, suatu organisasi (kelembagaan), atau suatu sistem untuk melaksanakan fungsi-fungsi atau kewenangannya untuk mencapai tujuannya secara efektif dan efisien.

\section{Kompetensi SDM memoderasi pengaruh penerapan SAKD terhadap kualitas laporan keuangan pemerintah daerah}

Dalam rangka mewujudkan pengelolaan keuangan daerah yang baik, pemerintah daerah harus menyampaikan laporan pertanggungjawaban yakni LKPD yang mengacu pada SAP. Dalam hal ini, sumber daya yang berkompeten sangatlah dibutuhkan, karena kompetensi dan kualitas sumber daya dapat mencapai kesuksesan pekerjaannya (Kartopawiro \& Susanto, 2018). Laporan keuangan menjadi input bagi pemerintah daerah untuk pelaksanaan pertanggungjawaban keuangan daerah. Pertanggungjawaban APBD berupa laporan keuangan tersebut menjadi bahan bagi DPRD dan masyarakat dalam mengevaluasi kinerja pemerintahan. SAKD sebagai alat atau sistem dalam menyusun laporan keuangan yang mana keberhasilannya dalam penerapan SAKD yang dapat 
meningkatkan kualitas dari laporan keuangan sangat tergantung pada kompetensi sumber daya manusia yang menjalankan SAKD. Maka dari itu dalam pengelolaannya dibutuhkan SDM yang memiliki kompetensi di bidang akuntansi untuk dapat memahami SAKD secara keseluruhan agar dapat tercipta laporan keuangan daerah yang berkualitas, dan terhindar dari salah saji, karena laporan keuangan yang disusun secara tertib memerlukan sumber daya manusia yang menguasai sistem akuntansi keuangan pemerintah daerah.

$H_{3}$ : Kompetensi SDM memperkuat pengaruh hubungan antara penerapan SAKD terhadap kualitas laporan keuangan pemerintah daerah

\section{Kompetensi SDM memoderasi pengaruh SPI terhadap kualitas laporan keuangan pemerintah daerah}

Sistem pengendalian intern adalah suatu perencanaan yang meliputi struktur organisasi dan semua metode yang dikoordinasikan di dalam organisasi dengan tujuan untuk menjaga keamanan harta yang dimiliki organisasi, memeriksa kebenaran dan ketelitian data akuntansi, mendorong efisiensi, serta mendorong dipatuhinya kebijakan manajemen yang telah ditetapkan (Pratolo dkk, 2016). Pemahaman yang tepat atas penerapan suatu sistem pengendalian intern tentunya tidak lepas dari peranan kompetensi sumber daya manusia yang menggunakannya. Pemahaman yang tepat akan sistem pengendalian intern memungkinkan penerapan yang konsisten serta pemanfaatan yang memberikan hasil yang lebih maksimal dalam pengelolaan ataupun penyusunan laporan keuangan pemerintah daerah.

$\boldsymbol{H}_{4}$ : Kompetensi SDM memperkuat pengaruh hubungan antara sistem pengendalian internal terhadap kualitas laporan keuangan pemerintah daerah.

Model penelitian pada penelitian ini adalah sebagai berikut:

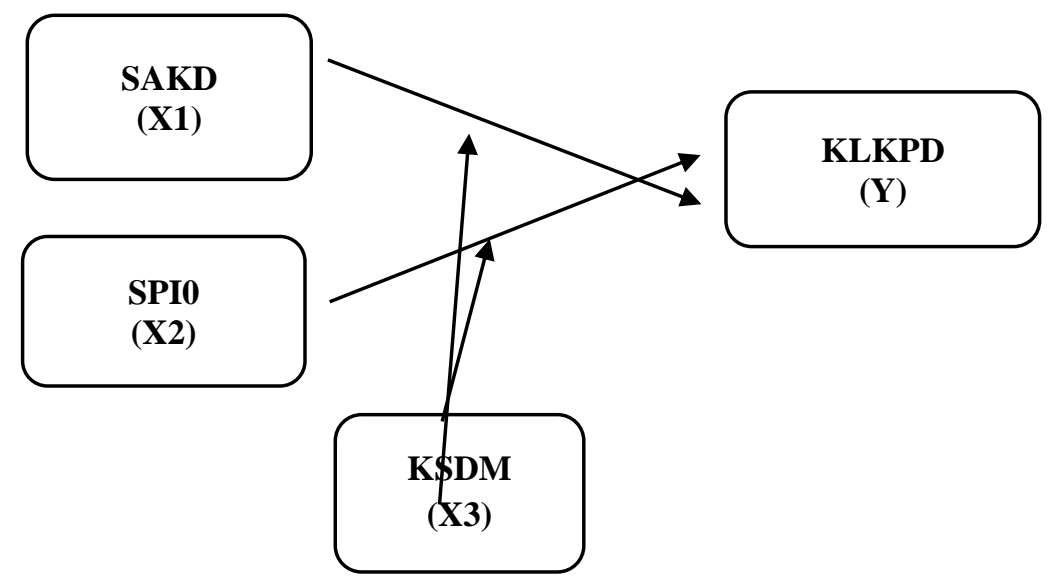

Gambar 1

Model Penelitian 


\section{METODE PENELITIAN}

\section{Objek Penelitian}

Objek yang digunakan dalam penelitian ini adalah seluruh SKPD di Lingkungan Pemerintah Kabupaten Klaten Jawa Tengah. Adapun yang menjadi sampel dalam penelitian ini adalah pegawai sub bagian akuntansi atau keuangan di setiap dinas.

\section{Jenis Data}

Data penelitian yang digunakan adalah data primer yaitu data penelitian yang diperoleh atau dikumpulkan langsung dari sumber asli (tanpa perantara).

\section{Teknik Pengambilan Sampel}

Pengambilan sampel dalam penelitian ini menggunakan teknik purposive sampling dengan pertimbangan peneliti memilih anggota sampel yang sekiranya dapat memberikan prospek yang baik bagi perolehan data yang akurat. Sampel dalam penelitian ini adalah staff bagian akuntansi atau penatausahaan keuangan yang sudah bekerja selama 1 tahun lebih pada SKPD di Kabupaten Klaten. Kriteria tersebut didasarkan pertimbangan sampel yang telah memahami penyusunan laporan keuangan.

\section{Teknik Pengumpulan Data}

Teknik pengumpulan data yang digunakan dalam penelitian ini yaitu kuisioner dengan pernyataan-pernyataan secara terstruktur dan menyebarkan kuisioner tersebut kepada pihak-pihak yang bersangkutan guna memperoleh informasi yang dibutuhkan. Kuisioner penelitian ini diserahkan langsung kepada responden atau dengan meminta bantuan salah satu pegawai pada masing-masing pegawai SKPD untuk mengkoordinasi penyebaran dan pengumpulan kuisioner pada SKPD tersebut.

\section{Definisi Operasional Variabel}

\section{Variabel Dependen}

Penelitian ini menggunakan kualitas laporan keuangan pemerintah daerah sebagai variabel dependen. Kualitas laporan keuangan diartikan sebagai laporan keuangan yang menyajikan informasi dapat difahami dan bermanfaat bagi penggunanya dalam pembuatan keputusan, jujur, tidak disalah gunakan, tidak ada kesalahan, sehingga dapat dibandingkan dengan periode sebelumnya. Kualitas laporan keuangan juga dapat didefinisikan sebagai laporan keuangan yang memenuhi empat karakteristik kualitatif yang menjadi tolak ukur yang telah ditetapkan oleh pemerintah. Laporan keuangan pemerintah daerah sendiri meliputi sekumpulan laporan dan berbagai penjelasan terstruktur yang berisi gambaran mengenai aktivitas pemerintah daerah.

\section{Variabel Independen}

\section{Sistem Akuntansi Keuangan Daerah}

Sistem akuntansi keuangan daerah merupakan rangkaian prosedur dalam pertanggungjawaban pelaksanaan APBD yang dilakukan secara manual atau menggunakan komputer, prosedur yang dimaksudkan disini meliputi mulai dari proses pengumpulan data, pencatatan, pengikhtisaran hingga pelaporan keuangan (Permendagri Nomor 59 Tahun 2007). 


\section{Sistem Penegndalian Intern}

Sistem pengendalian internal adalah penerapan kebijakan atau prosedur yang ditetapkan oleh pemerintah untuk menilai apakah organisasi telah mencapai tujuannya. Adapun fungsi dari adanya sistem pengendalian intern untuk mencegah kecurangan yang mungkin terjadi dan menjamin terselenggaranya aturan dan hukum yang diberlakukan.

\section{Variabel moderasi}

Variabel moderasi adalah suatu variabel independen lainnya yang dimasukkan ke dalam model karena mempunyai efek kontingensi dari hubungan variabel dependen dan variabel independen sebelumnya (Jogiyanto, 2016). Penelitian ini menggunakan kompetensi sumber daya manusia sebagai variabel moderasi.

Kompetensi sumber daya manusia adalah kemampuan yang dimiliki oleh setiap manusia dalam organisasi untuk mewujudkan tujuan organisasi dengan cara mengelola sumber daya dan mempertanggungjawabkannya. Sumber daya manusia yang memiliki kualitas dapat digambarkan sebagai individu yang memiliki kemampuan untuk mengelola potensi di dalam dirinya dan mampu beradaptasi dalam berbagai kondisi dimana individu tersebut akan memaksimalkan kemampuan dirinya untuk mengelola potensi-potensi dan sumber daya disekitarnya agar dapat mencapai kesejahteraan pada kehidupannya.

\section{HASIL DAN PEMBAHASAN}

\section{Gambaran Umum Objek/Subjek Penelitian}

Penelitian ini bertujuan untuk mengetahui Pengaruh Sistem Akuntansi Keuangan Daerah, Sistem Pengendalian Internal, dan Kompetensi Sumber Daya Manusia terhadap Kualitas Laporan Keuangan Pemerintah Daerah pada Satuan Kerja Perangkat Daerah Kabupaten Klaten. Objek dalam penelitian ini adalah 50 SKPD di Kabupaten Klaten. Dalam penelitian ini subjek yang digunakan adalah pegawai bagian akuntansi atau penatausahaan keuangan yang sudah bekerja selama 1 tahun lebih pada SKPD di Kabupaten Klaten. Berdasarkan survey yang dilakukan peneliti selama bulan Agustus sampai dengan September 2019, peneliti menyebarkan 100 kuisioner dengan jangka waktu pengambilan kuisioner tersebut 10 hari setelah waktu penyebaran. Total pengembalian kuisioner yang diperoleh peneliti yaitu sebanyak 88 .

\section{Statistik Deskriptif}

Statistik deskriptif variabel penelitian disajikan pada tabel 2 berikut ini:

Tabel 2

Hasil Uji Deskriptif Jawaban Responden

\begin{tabular}{lcccccc}
\multicolumn{1}{c}{ Variabel } & N & $\begin{array}{c}\text { Kisaran } \\
\text { Teoritis }\end{array}$ & $\begin{array}{c}\text { Kisaran } \\
\text { Aktual }\end{array}$ & $\begin{array}{c}\text { Median } \\
\text { Teoritis }\end{array}$ & $\begin{array}{c}\text { Mean } \\
\text { Aktual }\end{array}$ & Std. Deviation \\
\hline $\begin{array}{l}\text { Kualitas Laporan } \\
\text { Keuangan Pemerintah }\end{array}$ & 88 & $13-70$ & $50-70$ & 41,5 & 61,57 & 4,660 \\
$\begin{array}{l}\text { Daerah } \\
\text { Sistem Akuntansi }\end{array}$ & 88 & $6-30$ & $21-30$ & 18 & 26,81 & 2,284 \\
$\begin{array}{l}\text { Keuangan Daerah } \\
\begin{array}{l}\text { Sistem Pengendalian } \\
\text { Intern }\end{array}\end{array}$ & 88 & $15-80$ & $60-80$ & 47,5 & 69,53 & 4,768 \\
$\begin{array}{l}\text { Kompetensi Sumberdaya } \\
\text { Manusia }\end{array}$ & 88 & $10-50$ & $31-50$ & 30 & 43,60 & 3,970 \\
\hline
\end{tabular}

(Sumber : Data Primer-diolah 2019) 
Berdasarkan tabel 2 dapat dilihat angka pada median teoritis dengan mean aktual yang mana nilai pada masing-masing variabel mengindikasikan bahwa semakin baik penerapan sistem akuntansi keuangan daerah, sistem pengendalian intern, dan kompetensi yang dimiliki sumberdaya manusia maka kualitas dari laporan keuangan akan semakin baik.

\section{Uji Validitas}

Tabel 3

Hasil Uji Validitas

\begin{tabular}{|c|c|c|c|c|c|}
\hline Variabel & $\begin{array}{l}\text { Nilai } \\
\text { KMO }\end{array}$ & Item & $\begin{array}{l}\text { Nilai } \\
\text { loading } \\
\text { factor }\end{array}$ & Sig & Kriteria \\
\hline Kualitas Laporan Keuangan & $0,839 \geq 0,5$ & KLK1 & 0,723 & 0,000 & \multirow{6}{*}{ Valid } \\
\hline \multirow[t]{12}{*}{ Pemerintah Daerah } & & KLK2 & 0,748 & 0,000 & \\
\hline & & KLK3 & 0,678 & 0,000 & \\
\hline & & KLK4 & 0,740 & 0,000 & \\
\hline & & KLK5 & 0,590 & 0,000 & \\
\hline & & KLK6 & 0,792 & 0,000 & \\
\hline & & KLK7 & 0,592 & 0,000 & \multirow{7}{*}{ Valid } \\
\hline & & KLK8 & 0,713 & 0,000 & \\
\hline & & KLK9 & 0,505 & 0,000 & \\
\hline & & KLK10 & 0,534 & 0,000 & \\
\hline & & KLK11 & 0,499 & 0,000 & \\
\hline & & KLK12 & 0,757 & 0,000 & \\
\hline & & KLK13 & 0,700 & 0,000 & \\
\hline Sistem Akuntansi Keuangan & $0,805 \geq 0,5$ & SAKD1 & 0,618 & 0,000 & \multirow{6}{*}{ Valid } \\
\hline \multirow[t]{5}{*}{ Daeah } & & SAKD2 & 0,766 & 0,000 & \\
\hline & & SAKD3 & 0,756 & 0,000 & \\
\hline & & SAKD4 & 0,714 & 0,000 & \\
\hline & & SAKD5 & 0,734 & 0,000 & \\
\hline & & SAKD6 & 0,708 & 0,000 & \\
\hline \multirow[t]{15}{*}{ Sistem Pengendalian Intern } & $0,801 \geq 0,5$ & SPI1 & 0,466 & 0,000 & \multirow{15}{*}{ Valid } \\
\hline & & SPI2 & 0,427 & 0,000 & \\
\hline & & SPI3 & 0,441 & 0,000 & \\
\hline & & SPI4 & 0,633 & 0,000 & \\
\hline & & SPI5 & 0,584 & 0,000 & \\
\hline & & SPI6 & 0,560 & 0,000 & \\
\hline & & SPI7 & 0,731 & 0,000 & \\
\hline & & SPI8 & 0,720 & 0,000 & \\
\hline & & SPI9 & 0,566 & 0,000 & \\
\hline & & SPI10 & 0,572 & 0,000 & \\
\hline & & SPI11 & 0,488 & 0,000 & \\
\hline & & SPI12 & 0,676 & 0,000 & \\
\hline & & SPI13 & 0,531 & 0,000 & \\
\hline & & SPI14 & 0,737 & 0,000 & \\
\hline & & SPI15 & 0,733 & 0,000 & \\
\hline Kompetensi & $0,818 \geq 0,5$ & SDM1 & 0,692 & 0,000 & \multirow{10}{*}{ Valid } \\
\hline \multirow[t]{9}{*}{ Sumber Daya Manusia } & & SDM2 & 0,729 & 0,000 & \\
\hline & & SDM3 & 0,664 & 0,000 & \\
\hline & & SDM4 & 0,818 & 0,000 & \\
\hline & & SDM5 & 0,804 & 0,000 & \\
\hline & & SDM6 & 0,778 & 0,000 & \\
\hline & & SDM7 & 0,605 & 0,000 & \\
\hline & & SDM8 & 0,584 & 0,000 & \\
\hline & & SDM9 & 0,605 & 0,000 & \\
\hline & & SDM10 & 0,584 & 0,000 & \\
\hline
\end{tabular}

(Sumber: Data Primer, diolah 2019) 
Tabel 3 menunjukkan bahwa masing-masing variabel memiliki nilai $\mathrm{KMO} \geq 0,5$ dan setiap instrumennya memiliki nilai loading factor $\geq 0,3$ atau lebih yang artinya instrumen penelitian yang digunakan dapat dikatakan layak dan valid.

\section{Uji Reliabilitas}

Tabel 4

Hasil Uji Reliabilitas

\begin{tabular}{lcc}
\hline \multicolumn{1}{c}{ Variabel } & Cronbach Alpha & Kriteria \\
\hline Kualitas Laporan Keuangan Pemerintah & 0,871 & \\
Daerah (Y) & 0,810 & Reliabel \\
Sistem Akuntansi Keuangan Daerah (X1) & 0,870 & \\
Sistem Pengendalian Intern (X2) & 0,861 & \\
Kompetensi Sumber Daya Manusia (X3) &
\end{tabular}

(Sumber: Data Primer, diolah 2019)

Tabel 4 menunjukkan bahwa nilai Cronbach Alpha dari masing-masing konstruk lebih besar dari 0,50 yang berarti bahwa kuisioner yang merupakan indikator-indikator dari variabel atau konstruk tersebut reliabel.

\section{Uji Normalitas}

Tabel 5

Hasil Uji Normalitas

\begin{tabular}{|c|c|c|c|}
\hline Model & Kolmogorov Sminorv & Sig & Keterangan \\
\hline Model 1 & 0,665 & 0,769 & Berdistribusi \\
\hline Model 2 & 0,587 & 0,881 & Normal \\
\hline
\end{tabular}

(Sumber: Data Primer, diolah 2019)

Berdasarkan tabel 5 hasil uji normalitas regresi untuk persamaan 1 dan persamaan 2 diketahui bahwa nilai asymp sig. (2-tailed) lebih besar dari 0,05 sehingga asumsi klasik untuk uji normalitas terpenuhi dan dapat disimpulkan bahwa data yang digunakan berdistribusi normal.

\section{Uji Multikoliniearitas}

Tabel 6

Hasil Uji Multikolinearitas

\begin{tabular}{clccc}
\hline \multicolumn{1}{c}{ Model Regresi } & \multicolumn{1}{c}{ Variabel } & tolerance & VIF & Keterangan \\
\hline \multirow{3}{*}{ Model 1 } & Sistem Akuntansi & 0,788 & 1,270 & \\
& $\begin{array}{l}\text { Keuangan Daerah } \\
\text { Sistem Pengendalian }\end{array}$ & 0,806 & 1,240 & \\
& $\begin{array}{l}\text { Intern } \\
\text { Sistem Akuntansi }\end{array}$ & 0,564 & 5,867 & Bebas dari \\
& $\begin{array}{l}\text { Keuangan Daerah } \\
\text { Sistem Pengendalian }\end{array}$ & 0,732 & 6,960 & Multikolinearitas \\
& Intern & 0,753 & 1,328 & \\
& Kompetensi SDM & 0,669 & 5,953 & \\
& MRA & & & \\
& (SAKD ${ }^{*}$ SDM) & 0,845 & 1,040 & \\
& MRA & & & \\
& $\left(\right.$ SPI ${ }^{*}$ SDM) & & & \\
\end{tabular}

(Sumber: Data Primer, diolah 2019) 
Berdasarkan tabel uji multikolineritas di atas, dapat ditunjukkan bahwa semua variabel penelitian memiliki nilai tolerance $\geq 0,1$ dan nilai VIF $\leq 10$ sehingga dapat disimpulkan tidak terdapat multikolinearitas antar variabel bebas pada model regresi yang digunkan dalam penelitian.

Uji Heteroskedastisitas

Tabel 7

Hasil Uji Heteroskedastisitas

\begin{tabular}{|c|c|c|c|}
\hline Model Regresi & Variabel & Sig. & Keterangan \\
\hline \multirow{5}{*}{ Model 1} & Sistem Akuntansi Keuangan Daerah & 0.335 & \\
\hline & Sistem Pengendalian Intern & 0,402 & \\
\hline & Sistem Akuntansi Keuangan Daerah & 0,741 & \\
\hline & Sistem Pengendalian Intern & 0,417 & \\
\hline & Kompetensi SDM & 0,467 & Homoskedastisitas \\
\hline \multirow[t]{3}{*}{ Model 2} & MRA & 0,654 & \\
\hline & $\left(\mathrm{SAKD}^{*} \mathrm{KSDM}\right)$ & 0,054 & \\
\hline & $\begin{array}{l}\text { MRA } \\
\left(\mathrm{SPI}^{*} \mathrm{KSDM}\right)\end{array}$ & 0,713 & \\
\hline
\end{tabular}

(Sumber: Data Primer, diolah 2019)

Berdasarkan tabel hasil uji heteroskedastisitas di atas, seluruh variabel bebas pada analisis regresi tidak mengalami gejala heteroskedastisitas dengan nilai signifikan untuk masing-masing variabel independen $\geq 0,05$.

Uji Hipotesis dan Analisis Data

Tabel 8

Hasil Uji Regresi Linier Berganda Model 1

\begin{tabular}{|c|c|c|}
\hline Variabel & $\begin{array}{c}\text { Unstandardized Coefficients } \\
\text { B }\end{array}$ & Sig \\
\hline (Constant) & 12,928 & \\
\hline SAKD & 0,005 & 0,979 \\
\hline SPI & 0,449 & 0,000 \\
\hline $\mathrm{F}$ & 22,811 & \\
\hline Sig. F & 0,000 & \\
\hline Adjusted R Square & 0,429 & \\
\hline
\end{tabular}

(Sumber: Data Primer, diolah 2019)

Berdasarkan hasil uji regresi pada table diatas dapat disimpulkan bahwa:

\section{Hasil Uji Koefisien Determinasi}

Berdasarkan tabel 7 diatas hasil uji determinasi model 1 mendapatkan nilai Adjusted R Square 0,429 yang berarti 42,9\% variasi besarnya Kualitas Laporan Keuangan Daerah (KLKD) dapat dijelakan oleh penerapan Sistem Akuntansi Keuangan Daerah (SAKD) dan Sistem Pengendalian Intern (SPI) lalu untuk sisanya yaitu 57,1\% dijelaskan oleh variabel lain di luar model.

\section{Uji F}

Berdasarkan tabel diatas nilai signifikan yang diperoleh sebesar $0,000 \leq 0,05$ maka dapat disimpulkan bahwa model yang digunakan adalah baik dengan tingkat kepercayaan $=0,05$, berrati variabel Penerapan Sistem Akuntansi Keuangan Daerah (SAKD) dan Sistem Pengendalian Intern (SPI) secara bersama-sama berpengaruh terhadap variabel Kualitas Laporan Keuangan Daerah. 


\section{Uji Hipotesis $1(\mathrm{H} 1)$}

Berdasarkan hasil uji regresi diatas variabel sistem akuntansi keuangan daerah memiliki nilai sig 0,979 $\geq 0,05$ dengan nilai koefisien sebesar 0,005. Dapat disimpulkan bahwa sistem akuntansi keuangan daerah berpengaruh negatif terhadap kualitas laporan keuangan pemerintah daerah. Hasil ini menunjukkan bahwa $\mathrm{H} 1$ tidak berhasil didukung.

\section{Uji Hipotesis 2 (H2)}

Berdasarkan tabel 7 variabel sistem pengendalian intern memiliki nilai sig $0,000 \leq 0,05$ dengan nilai koefisien sebesar 0,449. Dapat disimpulkan bahwa sistem pengendalian intern berpengaruh positif terhadap kualitas laporan keuangan pemerintah daerah. Hasil ini menunjukkan bahwa H2 berhasil didukung.

Tabel 9

Hasil Perhitungan MRA Hipotesis 3 dan 4

\begin{tabular}{lcc}
\hline \multicolumn{1}{c}{ Model } & Unstandardized Coefficients & Sig \\
\hline (Constant) & B & \\
Sistem Akuntansi Keuangan Daerah & $-1,904$ & 0,853 \\
Sistem Pengendalian Intern & 0,387 & 0,619 \\
Kompetensi Sumber Daya Manusia & 0,517 & 0,001 \\
SAKD ${ }^{*}$ KSDM & 0,396 & 0,004 \\
SPI $^{*}$ KSDM & 0,009 & 0,008 \\
\hline
\end{tabular}

(Sumber: Data Primer, diolah 2019)

Berdasarkan hasil uji regresi pada tabel 9 di atas dapat disimpulkan bahwa:

\section{Uji Hipotesis 3 (H3)}

Berdasarkan tabel 9 variabel moderasi SAKD * KSDM memiliki nilai sig $0,004 \leq 0,05$ dengan nilai koefisien sebesar 0,009. Hal ini dapat disimpulkan bahwa kompetensi sumberdaya manusia berpengaruh positif terhadap hubungan antara sistem akuntansi keuangan daerah dengan kualitas laporan keuangan pemerintah daerah. Hasil ini menunjukkan bahwa $\mathrm{H} 3$ berhasil didukung.

\section{Uji Hipotesis 4 (H4)}

Tabel 9 menunjukkan bahwa variabel moderasi SPI ${ }^{*}$ KSDM memiliki nilai sig 0,008 $\leq 0,05$ dengan nilai koefisien sebesar 0,002. Dapat disimpulkan bahwa kompetensi sumberdaya manusia berpengaruh positif terhadap hubungan antara sistem pengendalian intern dengan kualitas laporan keuangan pemerintah daerah. Hasil ini menunjukkan bahwa $\mathrm{H} 4$ berhasil didukung.

\section{Pembahasan}

\section{Pengaruh Penerapan SAKD Terhadap Kualitas Laporan Keuangan Pemerintah Daerah}

Berdasarkan analisis statistik dalam penelitian ini ditemukan bahwa H1 tidak berhasil didukung dan disimpulkan bahwa penerapan sistem akuntansi keuangan daerah tidak berpengaruh terhadap kualitas laporan keuangan pemerintah daerah. Hasil penelitian ini konsisten dengan penelitian yang dilakukan oleh Kartopawiro dan Susanto (2018) yang membuktikan bahwa sistem akuntansi keuangan daerah tidak berpengaruh terhadap kualitas laporan keuangan pemerintah daerah. 
Dalam hasil uji statistik deskriptif menunjukkan bahwa responden memberikan jawaban yang besar terhadap variabel sistem akuntansi keuangan daerah, yang artinya pada Pemerintah Kabupaten Klaten telah menerapkan sistem akuntansi keuangan daerah secara optimal dalam menyusun laporan keuangan. Hal tersebut bertentangan dengan hasil penelitian yang mengatakan bahwa sistem akuntansi keuangan daerah tidak berpengaruh terhadap kualitas laporan keuangan, hal ini menunjukkan bahwa walaupun dalam penyusunan laporan keuangan sudah baik namun bukan menjadi tolak ukur untuk menentukan baik atau buruknya kualitas laporan keuangan, namun berdasarkan jawaban kuisioner masih terjadi pencatatan yang dilakukan secara tidak kronologis, hal ini juga dapat memengaruhi kualitas dari laporan keuangan karena apabila semua komponen-komponen dilakukan dengan baik maka hal tersebut mampu meningkatkan kualitas laporan keuangan.

\section{Pengaruh Penerapan Sistem Pengendalian Intern terhadap Kualitas Laporan Keuangan Pemerintah Daerah}

Hasil uji hipotesis dalam penelitian ini menunjukkan hipotesis kedua yaitu Sistem Pengendalian Intern berpengaruh positif terhadap Kualitas Laporan Keuangan Pemerintah Daerah. Berdasarkan pengolahan data yang dilakukan maka dinyatakan hipotesis kedua berhasil didukung. Hipotesis terdukung sesuai dengan teori stewardship dimana pemerintah sebagai steward yang mengelola sumber daya dan masyarakat sebagai pemilik. Pemerintah sebagai steward memiliki tugas melayani publik dan juga mensejahterakan masyarakat.

Hal ini dapat diketahui bahwa dalam lingkungan Pemerintah Daerah Kabupaten Klaten telah menerapkan SPI secara optimal karena sistem pengendalian intern dalam suatu organisasi menjadi hal yang utama dan sangat dibutuhkan karena suatu kegiatan operasional memerlukan suatu kebijakan khusus yang mampu membatasi dan mengkoordinisasi dalam setiap kegiatan yang dilaksanakan. Hasil penelitian ini konsisten dengan penelitian yang dilakukan oleh Kiranayanti dan Erawati (2016) serta Munasyir (2015) yang membuktikan bahwa sistem pengendalian intern berpengaruh positif terhadap kualitas laporan keuangan pemerintah daerah.

\section{Kompetensi SDM Memoderasi Pengaruh Penerapan SAKD terhadap Kualitas Laporan Keuangan Pemerintah Daerah}

Hasil uji hipotesis 3 menunjukkan bahwa Kompetensi Sumber Daya Manusia berpengaruh positif terhadap hubungan antara Penerapan Sistem Akuntansi Keuangan Daerah dengan Kualitas Laporan Keuangan Pemerintah Daerah sehingga hipotesis keempat berhasil didukung. Hipotesis terdukung sejalan dengan teori kompetensi spancer, dalam teori ini kompetensi mengacu pada kemampuan, pengetahuan dan perilaku. Kemampuan merupakan strategi yang diarahkan untuk meningkatkan efektifitas dan efisiensi dalam meningkatkan suatu kinerja.

Hasil penelitian ini mengemukakan bahwa kompetensi sumber daya manusia sangat berperan penting dalam menerapkan sistem akuntansi keuangan daerah demi tercapainya laporan keuangan daerah yang berkualitas. Organisasi sektor publik dalam hal ini adalah SKPD dalam menerapkan sistem akuntansi keuangan daerah hendaknya m emiliki sumber daya yang berkompetensi sesuai dengan kemampuannya agar keberhasilan suatu organisasi dapat mencapai tujuan yang maksimal.

\section{Kompetensi SDM Memoderasi Pengaruh Penerapan SPI terhadap Kualitas Laporan Keuangan Pemerintah Daerah}

Hasil uji hipotesis 4 menunjukkan bahwa Kompetensi SDM berpengaruh positif terhadap Kualitas Laporan Keuangan Pemerintah Daerah sehingga hipotesis keempat berhasil didukung. Hipotesis terdukung sejalan dengan teori kompetensi spancer, teori ini mengacu kepada kemampuan, perilaku dan pengetahuan yang dimiliki seseorang untuk meningkatkan efektifitas dan efisiensi dalam menigkatkan kinerja. Hal ini menunjukkan bahwa sumber daya manusia yang berkompeten mendukung suatu aktivitas berjalan dengan baik. Oleh karena itu dalam pengelolaan 
keuangan daerah, pemerintah daerah menerapkan unsur-unsur pengendalian intern dengan menempatkan pihak-pihak yang terlibat didalamnya. Pemahaman yang tepat atas penerapan suatu sistem pengendalian inter tentunya tidak lepas dari peranan kompetensi sumber daya manusia yang menggunakannya. Pemahaman yang tepat akan sistem pengendalian intern memungkinkan penerapan yang konsisten memberikan hasil maksimal dalam pengelolaan laporan keuangan pemerintah daerah. Hasil penelitian ini konsisten dengan penelitian yang dilakukan oleh Agustiawan \& Rasmini (2016) yang membuktikan kompetensi sumberdaya manusia mampu memperkuat hubungan antara sistem pengendalian intern dengan kualitas laporan keuangan pemerintah daerah.

\section{KESIMPULAN}

Penelitian ini menemukan bahwa penerapan SAKD tidak berpengaruh terhadap kualitas laporan keuangan, dan SPI berpengaruh positif terhadap kualitas laporan keuangan. Penelitian ini juga menemukan bahwa kompetensi sumberdaya manusia memiliki peran penting dalam meningkatkan kualitas laporan keungan. Hal ini ditunjukkan dengan adanya pengaruh positif penerapan SAKD dan SPI terhadap kualitas laporan keuangan ketika SDM yang terkait dengaan penyusunan laporan keuangan memiliki kompetensi yang baik. Hal ini mengindikasi bahwa keberhasilan system sangat bergantung pada manusia-manusia yang menjalankan system tersebut.

Penelitian ini memiliki keterbatasan generalisasi penelitian karena sampel hanya pada SKPD di kabupaten Klaten. Penelitian selanjutnya dapat meneliti penerapan system lainnya dalam meningkatkan kualitas laporan keuangan, seperti penerapan system penganggaran berbasis kinerja, baik konvensional maupun berbasis teknologi informasi (e-perfomance based budgeting.

\section{DAFTAR PUSTAKA}

Agung, R. I. G. (2008). Audit Kinerja Pada Sektor Publik. Jakarta: Grafindo.

Agustiawan, N, T. \& Rasmini,N,K. (2016). Pengaruh Sistem Berbasis Akrual, TI, dan SPIP Pada Kulitas Laporan Keuangan dengan Komptensi SDM sebagai Moderasi. E-Jurnal Ekonomi dan Bisnis Universitas Udayana. 5(10), 3475-3500.

Andini, D. \& Yusrawati. (2015). Pengaruh Kompetensi Sumber Daya Manusia dan Penerapan Sistem Akuntansi Keuangan Daerah Terhadap Kualitas Laporan Keuangan Daerah pada Satuan Kerja Perangkat Daerah (SKPD) Kabupaten Empat Lawang Sumatera Selatan. Jurnal Ekonomi, Manajemen dan Akuntansi. 24(1), 65-82.

BPK Perwakilan Jawa Tengah. (2015). Annual Report BPK RI Perwakilan Jawa Tengah. Klaten BPK Perwakilan Jawa Tengah. 2016. Annual Report BPK RI Perwakilan Jawa Tengah. Klaten Budiawan, D. A. \& Purnomo, B. S. (2014). Pengaruh Pengendalian Internal dan Kekuatan Koersif Terhadap Kualitas Laporan Keuangan Pemerintah Daerah. Jurnal Riset Akuntansi dan Keuangan. 2(1). 276-288

COSO. (2013). Internal Control- Integrated Framework: Executive Summary. Durham, North Carolina.

Desipradani, G \& Nuraini, F. (2018). Variabel Berpengaruh Terhadap Kualitas Laporan Keuangan Pemerintah Kota Surabaya. Majalah Ekonomi. XXIII, 2.

Donaldson, L. \& James H. D. (1991). Stewardship Theory or Agency Theory : CEO Governance and shareholder Returns. Australian Journal of Management. 16(1), 49-65.

Firdaus, N. \& Fahlevi, H. (2015). Pengaruh Kualitas Sumber Daya Manusia, Pemanfaatan Teknologi Informasi dan Penerapan Kebijakan Akuntansi Terhadap Kualitas Laporan Keuangan Pemerintah Kota Banda Aceh

Ghozali, I. (2011). Aplikasi Analisis Multivariate dengan Program IBM dengan SPSS 19. Edisi 5. Badan Penerbit Universitas Diponegoro Semarang

Gomes, F. C. (2003). Manajemen Sumber Daya Manusia. Jakarta: Andi Offset. 
Halim, A. \& Kusufi, M. S. (2013). Akuntansi Keuangan Daerah. Jakarta: Penerbit Salemba Empat

Halim, A. (2002). Akuntansi Sektor Publik, Akuntansi Keuangan Daerah. Jakarta: Salemba Empat.

Hartono, J. (2016). Metode Penelitian Bisnis. Yogyakarta: BFE

Indriasari, D. \& Ertambang, N. (2008). Pengaruh Kapasitas Sumber Daya Manusai, Pemanfaatan Teknologi Informasi, dan Pengendalian Intern Akuntansi Terhadap Nilai Informasi Pelaporan Keuangan Pemerintah Daerah (Studi Pada Pemerintah Kota Palembang dan Kabupaten Ogan Ilir). Simposium Nasional Akuntansi IX. Pontianak.

Jensen \& Meckling. (1976). The Theory of The Firn: Manajerial Behaviour, Agency Cost, and Ownership Structure. Journal of Financial and Economics, 3, 305-360

Karsana \& Suaryana. (2017). Pengaruh Efektivitas Penerapan SAP, Kompetensi SDM, dan SPI pada Kualitas Laporan Keuangan Pemerintah Kabupaten Bangli. E-Jurnal Akuntansi Universitas Udayana. 21(1), 643-670.

Kartopawiro, S \& Susanto, Y. (2018). Analisis Terhadap Kinerja Laporan Keuangan Pemerintah Daerah Kabupaten Musi Rawas. Jurnal Manajemen dan Bisnis Sriwijaya. 16(1), 1-14.

Kiranayanti \& Erawati. (2016). Pengaruh Sumber Daya Manusia, Sistem Pengendalian Intern, Pemahaman Berbasis Akrual Terhadap Kualitas Laporan Keuangan Daerah. E-Jurnal Akuntansi Universitas Udayana. 16(2), 1290-1318.

Lillrank, P. (2003). The Quality of Information. International Journal of Quality and Reliability Management. 20(6), 691-703.

Mahaputra \& Putra. (2014). Analisis Faktor-Faktor Yang Memengaruhi Kualitas Informasi Pelaporan Keuangan Pemerintah Daerah. E-Jurnal Akuntansi Universitas Udayana. 8(2), 230.

Moehariono. (2009). Pengukuran Kinerja Berbasis Kompetensi. Bogor: Ghalia Indonesia

Munasyir. (2015). Pengaruh Penerapan Standar Akuntansi Pemerintahan dan Sistem Pengendalian Intern Pemerinta Terhadap Kualitas Laporan Keuangan Satuan Kerja Perangkat Daerah di Kabupaten Aceh Utara. Jurnal Magister Akuntansi Pascasarjana Universitas Syiah Kuala. 4(4), 23-35.

Nazaruddin, I. \& Basuki, A. T. (2016). Akuntansi Keuangan Pemerintah Daerah. LP3M UMY

Pemerintah Indonesia. (1999). Undang-Undang No 22 Tahun 1999 tentang Pemerintah Daerah: Republik Indonesia.

Pemerintah Indonesia. (1999). Undang-Undang No 25 Tahun 1999 tentang Perimbangan Keuangan Antara Pemerintah Pusat dan Daerah: Republik Indonesia

Pemerintah Indonesia. (2005). Peraturan Pemerintah Nomor 24 Tahun 2005 tentang Standar Akuntansi Pemerintah: Republik Indonesia

Pemerintah Indonesia. (2006). Peraturan Menteri Dalam Negeri Nomor 13 Tahun 2006 tentang Pengelolaan Keuangan Daerah: Republik Indonesia

Pemerintah Indonesia. (2007). Peraturan Menteri Dalam Negeri Nomor 59 Tahun 2007 tentang Pedoman Pengelolaan Keuangan Daerah: Republik Indonesia

Pemerintah Indonesia. (2010). Peraturan Pemerintah Nomor 71 Tahun 2010 tentang Standar Akuntansi Pemerintah: Republik Indonesia

Pratolo, S. Y. R. \& Sofyani, H. (2017). Analisis Statistik dengan SPSS. Danisa Media

Putra, F. D. (2018). Pengaruh Kapasitas Sumber Daya Manusia, Pemanfaatan Teknologi Informasi dan Pengendalian Intern terhadap Keterandalan Pelaporan Keuangan Pemerintah Daerah pada SKPD se-Kabupaten Bintan. JOM Fekom, 1(1), 1-13.

Raharjo, E. (2007). Teori Agensi dan Teori Stewardship dalam Perspektif Akuntansi. Fokus Ekonomi. 2(1), 37-46.

Rini, P. N. F. (2017). Pengaruh penerapan sistem akuntansi keuangan daerah, kompetensi sumber daya manusia, sistem pengendalian intern, dan pemanfaatn teknologi informasi terhadp kualitas laporan keuangan pemerintah daerah. Skripsi. Universitas Muhammadiyah Yogyakarta

Sekaran, U. (2006). Metodelogi Penelitian untuk Bisnis. Jakarta: Penerbit Salemba. 
Setiawati, E. \& Sari, S. P. (2014). Kualitas Laporan Keuangan Pemerintah Daerah Ditinjau dari Sumber Daya Manusia, Pengendalian Intern, Pemanfaatan Teknologi Informasi dan Pemahaman Akuntansi (Studi Empiris pada Pemerintah Kabupaten dan Kota di Wilayah Eks Keresidenan Surakarta). Naskah Publikasi Universitas Muhammadiyah Surakarta. Setyaningsih, R. R. (2016). Pengaruh Sistem Pengendalian Internal dan Kompetensi Staff Akuntansi Terhadap Kualitas Laporan Keuangan Puskesmas dengan Penerapan Standar Akuntansi Pemerintahan Sebagai Variabel Intervening (Studi Empiris pada Puskesmas di Provinsi Daerah Istimewa Yogyakarta). Skripsi. Universitas Muhammadiyah Yogyakarta

Soimah, S. (2014). Pengaruh Kapasitas Sumber Daya Manusia, Pemanfaatan Teknologi Informasi Dan Sistem Pengendalian Intern Pemerintah Terhadap Kualitas Laporam Keuangan Pemerintah Daerah Kabupaten Bengkulu Utara. Skripsi. Universitas Bengkulu.

Spencer, L. M. \& Spencer, S. M. (1993). Competence at Work: Models for Superior Performance. New York

Sugiyono. (2004). Metode Penelitian Kuantitatif Kualitatif dan R\&D. Bandung: CV ALFABETA Sugiyono. (2012). Metode Penelitian Kuantitatif, Kualitatif dan R\&D. Bandung: CV ALFABETA. Warren, S. C., Reeve, M. J., \& Fess, E. P. (2005). Corporate Financial Accounting. South Western: Thomson.

Yosefrinaldi. (2013). Pengaruh Kapasitas Sumber Daya Manusia dan Pemanfaatan Teknologi Informasi terhadap Kualitas Laporan Keuangan Pemerintah Daerah dengan Variabel Intervening Sistem Pengendalian Manajemen. Jurnal Akuntansi Universitas Negeri Padang. $1(1)$. 